\title{
GROWTH AND POST-HARVEST FRUIT QUALITY OF WEST INDIAN CHERRY UNDER SALINE WATER IRRIGATION AND POTASSIUM FERTILIZATION ${ }^{1}$
}

\author{
GEOVANI SOARES DE LIMA ${ }^{2 *}$, FRANCISCO WESLEY ALVES PINHEIRO ${ }^{3}$, HANS RAJ GHEYI ${ }^{3}$, LAURIANE \\ ALMEIDA DOS ANJOS SOARES ${ }^{2}$, SAULO SOARES DA SILVA ${ }^{3}$
}

\begin{abstract}
The study was conducted to evaluate the growth and physicochemical quality of West Indian cherry cv. BRS 366-Jaburu, as a function of saline water irrigation and potassium fertilization. The research was conducted under greenhouse conditions in Campina Grande-PB. The experimental design was randomized blocks in a $2 \times 4$ factorial arrangement, which consisted of two levels of irrigation water electrical conductivity - ECw $\left(0.8\right.$ and $\left.3.8 \mathrm{dS} \mathrm{m}^{-1}\right)$ and four levels of potassium of 50, 75, 100 and $125 \%$ of the recommendation, in

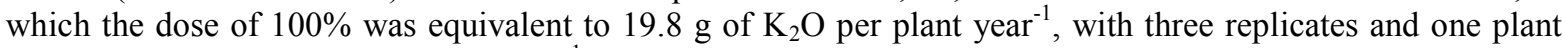
per replicate. Water salinity of $3.8 \mathrm{dS} \mathrm{m}^{-1}$ inhibited the absolute and relative growth in diameter of the rootstock and scion of West Indian cherry plants, in the period from 100 to 465 days after transplanting. The interaction between saline levels and potassium doses was significant for hydrogen potential, soluble solids and anthocyanins levels in BRS 366-Jaburu West Indian cherry fruits, with the highest values obtained in plants fertilized with 125,125 and $50 \%$ of the $\mathrm{K}_{2} \mathrm{O}$ recommendation and under water salinity of $3.8,3.8$ and $0.8 \mathrm{dS} \mathrm{m}$ ${ }^{1}$, respectively. Increasing doses of $\mathrm{K}$ did not attenuate the effects of salt stress on the relative growth in rootstock stem diameter, fruit polar diameter and anthocyanin contents of West Indian cherry. Soluble solid contents in West Indian cherry pulp increased with application of $\mathrm{K}_{2} \mathrm{O}$.
\end{abstract}

Keywords: Malphigia emarginata. Salt stress. Mitigation. Potassium.

\section{CRESCIMENTO E QUALIDADE PÓS-COLHEITA DE FRUTOS DE ACEROLEIRA IRRIGADA COM ÁGUAS SALINAS E ADUBAÇÃO POTÁSSICA}

RESUMO - O trabalho foi desenvolvido objetivando avaliar o crescimento e a qualidade físico-química de frutos de aceroleira cv. BRS 366-Jaburu, em função da irrigação com água salina e adubação potássica. A pesquisa foi realizada sob condições de casa de vegetação em Campina Grande-PB. Utilizaram-se o delineamento em blocos casualizados, em esquema fatorial $2 \times 4$, sendo dois níveis de condutividade elétrica da água de irrigação - $\mathrm{CEa}\left(0,8\right.$ e 3,8 $\left.\mathrm{dS} \mathrm{m}^{-1}\right)$ e doses de potássio de 50, 75; 100 e 125\% da recomendação, sendo a dose correspondente a $100 \%$ igual a 19,8 g de $\mathrm{K}_{2} \mathrm{O}$ por planta ano ${ }^{-1}$, com três repetições e uma planta por parcela. A utilização de água com salinidade de $3,8 \mathrm{dS} \mathrm{m}^{-1}$ inibiu o crescimento absoluto e relativo em diâmetro do porta-enxerto e do enxerto da aceroleira, no período de 100 a 465 dias após o transplantio. A interação entre os níveis salinos e as doses de potássio foi significativa para o potencial hidrogeniônico, os sólidos solúveis e teores de antocianinas em frutos de aceroleira BRS 366 -Jaburu, sendo os maiores valores obtidos nas plantas adubadas com 125,125 e $50 \%$ da recomendação de $\mathrm{K}_{2} \mathrm{O}$ e salinidade da água de 3,8; 3,8 e 0,8 dS $\mathrm{m}^{-1}$, respectivamente. Doses crescentes de potássio não atenuaram os efeitos do estresse salino sobre o crescimento relativo em diâmetro do porta-enxerto, o diâmetro polar dos frutos e os teores de antocianinas da aceroleira. Os teores de sólidos solúveis da polpa dos frutos de aceroleira aumentaram com aplicação de $\mathrm{K}_{2} \mathrm{O}$.

Palavras-chave: Malphigia emarginata. Estresse salino. Mitigação. Potássio.

\footnotetext{
"Corresponding author

${ }^{1}$ Received for publication in $01 / 13 / 2020$; accepted in 04/03/2020.

${ }^{2}$ Academic Unit of Agricultural Sciences, Center of Agrifood Science and Technology, Universidade Federal de Campina Grande, Pombal, PB, Brazil; geovani.soares@pq.cnpq.br - ORCID: 0000-0001-9960-1858, lauriane.soares@pq.cnpq.br - ORCID: 0000-0002-7689-9628. ${ }^{3}$ Academic Unit of Agricultural Engineering, Universidade Federal de Campina Grande, Campina Grande, PB, Brazil; wesley.ce@hotmail.com - ORCID: 0000-0002-5589-6882, hans@pq.cnpq.br - ORCID: 0000-0002-1066-0315, saulosoares90@gmail.com - ORCID: 0000-0002-1049-6519.
} 


\section{INTRODUCTION}

West Indian cherry (Malpighia emarginata L.) is a fruit crop cultivated in Brazil, especially in the northeastern semi-arid region, due to the favorable edaphoclimatic conditions for its cultivation. It stands out as a natural source of ascorbic acid and important bioactive compounds, such as anthocyanins, carotenoids, phenolic compounds, natural dyes, compounds with recognized effect on the prevention of degenerative diseases (DEMBITSKY et al., 2011). Its fruits can be either used for fresh consumption or industrialized in the form of frozen pulp and processed juices (CAVICHIOLI et al., 2014).

In the semi-arid region of Northeast Brazil, the poor spatial and temporal distribution of rainfalls, coupled to high temperatures, has contributed to gradual reduction in water availability, in both quantity and quality, and the occurrence of high contents of salts is common in both surface waters (small- and medium-sized dams) and subsurface waters (SILVA et al., 2014). For this reason, it becomes necessary to adopt management practices that allow saline waters to be used as a way to guarantee the agricultural production in this region, promoting socioeconomic and environmental development.

Salinity of water and/or soil stands out as one of the abiotic stresses that most limit plant growth and yield (MATIAS et al., 2018), because the accumulation of salt ions in plants causes osmotic stress, ionic toxicity and induces nutritional deficiencies (SILVA et al., 2011). Excess of salts (especially $\mathrm{Na}^{+}$and $\mathrm{Cl}^{-}$ions) leads to alterations in biochemical and photochemical processes of photosynthesis and may trigger oxidative stress due to the accumulation of reactive oxygen species (GOMES et al., 2017).

However, the salt concentrations that cause reduction in growth and post-harvest fruit quality of West Indian cherry may vary among species and cultivars, which exhibit different physiological behaviors regarding the effects of the stress caused by water and/or soil salinity. These effects depend on crop development stage, duration of exposure to stress, type of salt present in the medium, environmental conditions, cultural and irrigation managements, edaphoclimatic conditions and fertilization (SILVA et al., 2017).

Despite the inconveniences related to the use of saline waters in irrigation, some strategies can be adopted to mitigate the deleterious effects of their use in irrigation (COSTA et al., 2013), including fertilization with potassium (K). The importance of $\mathrm{K}$ fertilization in West Indian cherry cultivation is related to the functions performed by this macronutrient in the activation of enzymatic systems and reactions of phosphorylation, which are fundamental to metabolic processes, maintenance of ionic balance and cell turgor, control of stomatal opening and closure, synthesis and degradation of starch, and transport of carbohydrates in the phloem (MEDEIROS et al., 2008), playing a fundamental role in cell turgor and leaf transpiration (MELO et al., 2014).

In this context, the present study aimed to evaluate the growth and post-harvest fruit quality of West Indian cherry, cv. BRS 366-Jaburu, as a function of saline water irrigation and $\mathrm{K}$ fertilization.

\section{MATERIAL AND METHODS}

The experiment was conducted under greenhouse conditions from July 2016 to December 2017 , in pots adapted as drainage lysimeters, in the experimental area of the Center of Technology and Natural Resources of the Federal University of Campina Grande (CTRN/UFCG), located in the municipality of Campina Grande, $\mathrm{PB}$, Brazil $\left(7^{\circ} 15^{\text {' }}\right.$ $18^{\prime}, \mathrm{S}, 35^{\circ} 52^{\prime} 28^{\prime}, \mathrm{W}$ and altitude of $550 \mathrm{~m}$ ).

The experimental design was randomized blocks, with three replicates, in a $2 \times 4$ factorial arrangement, in which the treatments consisted of two levels of irrigation water electrical conductivity - ECw $\left(0.8\right.$ and $\left.3.8 \mathrm{dS} \mathrm{m}^{-1}\right)$ and four doses of $\mathrm{K}(50$, 75,100 and $125 \%$ of the recommendation). The dose relative to $100 \%$ corresponded to $19.8 \mathrm{~g}$ of $\mathrm{K}_{2} \mathrm{O}$ per plant year ${ }^{-1}$ (MUSSER, 1995).

The lysimeters were filled with a $1-\mathrm{kg}$ layer of crushed stone $\mathrm{n}^{\mathrm{o}} 0$, followed by $250 \mathrm{~kg}$ of a Neossolo Regolítico (Psamments) with sandy loam texture, properly pounded to break up clods, from the rural area of the municipality of Esperança, PB, whose chemical and physical characteristics were obtained according to the methodologies described by Teixeira et al. (2017): $\mathrm{Ca}^{2+}=9.07 \mathrm{cmol}_{\mathrm{c}} \mathrm{kg}^{-1}$; $\mathrm{Mg}^{2+}=2.78 \mathrm{cmol}_{\mathrm{c}} \mathrm{kg}^{-1} ; \mathrm{Na}^{+}=1.64 \mathrm{cmol}_{\mathrm{c}} \mathrm{kg}^{-1} ; \mathrm{K}^{+}=$ $0.23 \mathrm{cmol}_{\mathrm{c}} \mathrm{kg}^{-1} ; \mathrm{H}^{+}+\mathrm{Al}^{3+}=8.61 \mathrm{cmol}_{\mathrm{c}} \mathrm{kg}^{-1} ; \mathrm{Al}^{3+}=0$ $\mathrm{cmol}_{\mathrm{c}} \mathrm{kg}^{-1} ; \mathrm{CEC}=22.33 \mathrm{cmol}_{\mathrm{c}} \mathrm{kg}^{-1}$; organic matter $=$ $2.93 \mathrm{dag} \mathrm{kg}^{-1} ; \mathrm{P}=39.8 \mathrm{mg} \mathrm{kg}^{-1} ; \mathrm{pH}$ in water $(1: 2.5)$ $=5.58$; electrical conductivity of the saturation extract $=2.15 \mathrm{dS} \mathrm{m}^{-1} ; \mathrm{SAR}=0.67\left(\mathrm{mmol} \mathrm{L}^{-1}\right)^{0.5}$; exchangeable sodium percentage $=7.34 \%$; sand $=$ $659.9 \mathrm{~g} \mathrm{~kg}^{-1}$; silt $=161.2 \mathrm{~g} \mathrm{~kg}^{-1}$; clay $=178.9 \mathrm{~g} \mathrm{~kg}^{-1}$; moisture content at $33.42 \mathrm{kPa}=25.91 \mathrm{dag} \mathrm{kg}^{-1}$; moisture content at $1519.5 \mathrm{kPa}=12.96 \mathrm{dag} \mathrm{\textrm {kg } ^ { - 1 }}$.

A drain was installed at the bottom of each lysimeter, by using a 4-mm-diameter tube to drain the excess water into a container, in order to evaluate the drained water and determine water consumption by the plants. The tip of the drain inside the pot was involved in a nonwoven geotextile (Bidim OP 30) to avoid clogging by soil particles.

The experiment used seedlings of the West Indian cherry cv. BRS 366-Jaburu grafted onto rootstocks of heirloom seedlings, which came from EMBRAPA Tropical Agroindustry, located in Pacajus-CE. At transplanting, the seedlings were 240 
days old. During the acclimation period in the greenhouse (30 days after transplanting), the plants were irrigated with low-salinity water $\left(0.8 \mathrm{dS} \mathrm{m}^{-1}\right)$. After 30 days of transplanting, irrigation with different saline waters was started.

The cultivar BRS 366-Jaburu stands out for its high yield $\left(57 \mathrm{t} \mathrm{ha}^{-1}\right)$ and production of ascorbic acid $\left(2,648 \mathrm{mg} 100 \mathrm{~g}^{-1}\right)$. Plants are approximately $1.87 \mathrm{~m}$ tall with crown diameter of $2.18 \mathrm{~m}$. Its fruits are shiny, when ripe, and have mean weight of 4 to 5 $\mathrm{g}$ when unripe, ideal for obtaining vitamin $\mathrm{C}$, and 6 to $7 \mathrm{~g}$ after ripening (EMBRAPA, 2012).

Before transplanting the seedlings, the soil was brought to field capacity using the respective water of each treatment. After transplanting, irrigation was performed every day, applying in each lysimeter a water volume sufficient to maintain soil moisture close to field capacity. The volume applied was determined based on plant water needs, estimated by water balance: volume applied minus volume drained in the previous irrigation, plus a leaching fraction of 0.10 , applied at 30-day intervals.

Water with electrical conductivity of $3.8 \mathrm{dS} \mathrm{m}^{-1}$ was prepared by dissolving the salts $\mathrm{NaCl}$, $\mathrm{CaCl}_{2} \cdot 2 \mathrm{H}_{2} \mathrm{O}$ and $\mathrm{MgCl}_{2} \cdot 6 \mathrm{H}_{2} \mathrm{O}$, at equivalent proportion of $7: 2: 1$, respectively, in water from the public supply system $\left(\mathrm{ECw}=1.40 \mathrm{dS} \mathrm{m}^{-1}\right)$ of the municipality of Campina Grande, $\mathrm{PB}$, based on the relation between $\mathrm{ECW}$ and the concentration of salts (mmolc $\mathrm{L}^{-1}=10 * \mathrm{ECw} \mathrm{dS} \mathrm{m}^{-1}$ ), according to Richards (1954). Water with ECw of $0.8 \mathrm{dS} \mathrm{m}^{-1}$ was obtained by mixing rainwater $\left(\mathrm{ECW}=0.02 \mathrm{dS} \mathrm{m}^{-1}\right)$ with water from the municipal supply system $\left(\mathrm{ECW}=1.40 \mathrm{dS} \mathrm{m}^{-1}\right)$.

Fertilization with phosphorus and nitrogen was performed as recommended by Musser (1995), applying the equivalent to 250 and $53 \mathrm{~g}$ per plant year ${ }^{-1}$ of single superphosphate $\left(18 \%\right.$ of $\mathrm{P}_{2} \mathrm{O}_{5}, 16 \%$ of $\mathrm{Ca}^{2+}$ and $8 \%$ of $\mathrm{S}$ ) and urea $(45 \%$ of $\mathrm{N})$, respectively, whereas the dose of $\mathrm{K}$ was supplied according to the treatments, applying $33 \mathrm{~g}$ of potassium chloride $\left(60 \%\right.$ of $\left.\mathrm{K}_{2} \mathrm{O}\right)$ in the treatment corresponding to $100 \%$ of the recommendation. Phosphorus was applied entirely at planting, whereas nitrogen and potassium were split into 12 portions, applied monthly. To meet probable deficiencies of micronutrients, $5 \mathrm{~L}$ of solution containing $1.5 \mathrm{~g} \mathrm{~L}^{-1}$ of Ubyfol [(N (15\%); $\mathrm{P}_{2} \mathrm{O}_{5}(15 \%) ; \mathrm{K}_{2} \mathrm{O}(15 \%) ; \mathrm{Ca}$ (1\%); $\mathrm{Mg}$ (1.4\%); S (2.7\%); Zn (0.5\%); B (0.05\%); Fe $(0.5 \%)$; Mn (0.05\%); Cu (0.5\%); Mo (0.02\%)] was applied every week.

The growth of West Indian cherry cv. BRS 366-Jaburu was evaluated in the period from 100 to 465 days after transplanting (DAT) based on the absolute and relative growth rates in stem diameter of the rootstock $\left(A G R_{D R}\right.$ and $\left.R_{G R}\right)$ and scion $\left(A_{G R}\right.$ and $\left.R_{D R}\right)$. Post-harvest quality was determined at the end of the harvest (began at 180 DAT and continued until 515 DAT), when the fruits were red. After harvesting the fruits, a pre-cleaning was carried out to remove decayed fruits and impurities. Then, all fruits were washed three times in running water and sanitized in chlorinated solution $(1 \%)$ for $20 \mathrm{~min}$. The physical characterization of the fruits was performed based on their equatorial (FED) and polar (FPD) diameters. The physicochemical composition was determined through hydrogen potential $(\mathrm{pH})$, anthocyanin contents (ANT) and total soluble solids (SS).

The AGR and RGR in diameters of rootstock and scion of West Indian cherry were measured as recommended by Benincasa (2003), according to (Equation 1).

$$
\mathrm{RGR}=\frac{(\operatorname{InSD} 2-\operatorname{InSD} 1)}{(\mathrm{t} 2-\mathrm{t} 1)}
$$

Where: $\mathrm{RGR}=$ Relative growth rate in stem diameter $\left(\mathrm{mm} \mathrm{mm}^{-1} \mathrm{~d}^{-1}\right)$,

$\mathrm{SD}_{1}=$ Stem diameter $(\mathrm{mm})$ at time $\mathrm{t}_{1}$, (day); and,

$\mathrm{SD}_{2}=$ Stem diameter $(\mathrm{mm})$ at time $\mathrm{t}_{2}$, (day).

$\ln =$ natural logarithm

The AGR in diameter of rootstock and scion of West Indian cherry was determined according to (Equation 2):

$$
\mathrm{AGR}=\frac{(\mathrm{SD} 2-\mathrm{SD} 1)}{(\mathrm{t} 2-\mathrm{t} 1)}
$$

Where: $\mathrm{AGR}=$ Absolute growth rate in stem diameter of rootstock and scion $\left(\mathrm{mm} \mathrm{d}^{-1}\right)$,

$\mathrm{SD}_{1}=$ Stem diameter $(\mathrm{mm})$ at time $\mathrm{t}_{1}$, (day); and,

$\mathrm{SD}_{2}=$ Stem diameter $(\mathrm{mm})$ at time $\mathrm{t}_{2}$, (day).

The $\mathrm{pH}$ of West Indian cherry fruits was directly determined in the pulp using a digital $\mathrm{pH}$ meter calibrated in buffer solutions with $\mathrm{pH} 4.0$ and 7.0 (BRASIL, 2005). The content of soluble solids (SS) was determined by direct reading in a refractometer, according to methodology of the Association of Official Analytical Chemists International (AOAC, 1995). Anthocyanin contents were determined by readings in spectrophotometer at wavelength of $535 \mathrm{~nm}$, following the procedures described by Murray and Hackett (1991).

The data were subjected to analysis of variance by $F$ test and, when significant, means comparison test (Tukey test at 0.05 probability level) was conducted for water salinity levels (SL) and regression analysis was carried out for potassium doses (KD), using the statistical program Sisvar-Esal (FERREIRA, 2011).

\section{RESULTS AND DISCUSSION}

According to the summary of analysis of variance (Table 1), interaction between factors (SL x KD) was not significant for any of the variables analyzed, in the period from 100 to 465 days after 
transplanting. There was significant effect of the levels of irrigation water salinity on the AGRDR, AGRDS and RGRDS of West Indian cherry cv. BRS 366 Jaburu. Potassium doses significantly influenced only the RGRDR. Alvarenga et al. (2019), while evaluating the effect of different combinations of $\mathrm{N}$ and $\mathrm{K}$ doses on the growth of West Indian cherry cv. Flor Branca irrigated with saline waters (ECw ranging from 0.3 to $4.3 \mathrm{dS} \mathrm{m}^{-1}$ ), also found that there was no significant interaction between the factors for the growth variables analyzed.

Table 1. Summary of analysis of variance for absolute $\left(A G R_{D R}\right)$ and relative $\left(R_{G R}\right)$ growth rates in diameter of rootstock and absolute $\left(\mathrm{AGR}_{\mathrm{DS}}\right)$ and relative $\left(\mathrm{RGR}_{\mathrm{DS}}\right)$ growth rates in diameter of scion of West Indian cherry cv. BRS 366-Jaburu plants under saline water irrigation and potassium doses, in the period from 100 to 465 days after transplanting

\begin{tabular}{lccccc}
\hline \multirow{2}{*}{ Source of variation } & \multirow{2}{*}{$\mathrm{DF}$} & \multicolumn{4}{c}{ Mean squares } \\
\cline { 3 - 6 } & & $\mathrm{AGR}_{\mathrm{DR}}$ & $\mathrm{RGR}_{\mathrm{DR}}$ & $\mathrm{AGR}_{\mathrm{DS}}$ & $\mathrm{RGR}_{\mathrm{DS}}$ \\
\hline Saline levels (SL) & 1 & $0.00032^{* *}$ & $0.00000008^{\mathrm{ns}}$ & $0.00042^{* *}$ & $0.000001^{*}$ \\
K dose (KD) & 3 & $0.00002^{\text {ns }}$ & $0.0000002^{*}$ & $0.00004^{\mathrm{ns}}$ & $0.0000001^{\mathrm{ns}}$ \\
Linear regression & 1 & $0.00003^{\text {ns }}$ & $0.000001^{* *}$ & $0.00001^{\text {ns }}$ & $0.0000001^{\text {ns }}$ \\
Quadratic regression & 1 & $0.000009^{\text {ns }}$ & $0.0000001^{\mathrm{ns}}$ & $0.00009^{\text {ns }}$ & $0.0000001^{\text {ns }}$ \\
Interaction (SL x KD) & 3 & $0.000015^{\text {ns }}$ & $0.00000001^{\mathrm{ns}}$ & $0.0000003^{\text {ns }}$ & $0.000000001^{\text {ns }}$ \\
Blocks & 2 & $0.000007^{\text {ns }}$ & $0.000000002^{\text {ns }}$ & $0.0000002^{\text {ns }}$ & $0.00000001^{\text {ns }}$ \\
Residue & 14 & 0.000017 & 0.0000002 & 0.00001 & 0.0000001 \\
\hline CV (\%) & & 7.18 & 4.81 & 7.94 & 6.94
\end{tabular}

ns, *, ** Respectively, not significant, significant at $\mathrm{p}<0.05$ and $\mathrm{p}<0.01$.

The absolute growth rate in stem diameter of rootstock of West Indian cherry was inhibited by the irrigation with saline water in the period from 100 to 465 DAT and, according to the means comparison test (Figure 1A), plants irrigated using water with highest level of electrical conductivity $\left(3.8 \mathrm{dS} \mathrm{m}^{-1}\right)$ were significantly different from those subjected to the lowest ECw level $\left(0.8 \mathrm{dS} \mathrm{m}^{-1}\right)$. In a comparison between plants grown under ECW of $3.8 \mathrm{dS} \mathrm{m}^{-1}$ and those subjected to the lowest salinity level $(0.8$ $\left.\mathrm{dS} \mathrm{m} \mathrm{m}^{-1}\right)$, the $\mathrm{AGR}_{\mathrm{DR}}$ decreased by $12.09 \%(0.00737$ $\left.\mathrm{mm} \mathrm{d}^{-1}\right)$. Under conditions of high water salinity, the reduction in plant growth occurs due to the osmotic effect and, consequently, the increase in the osmotic pressure of the medium, leading to reduction in water availability to plants, affecting cell division and turgor, resulting in inhibition of cell wall expansion (ACOSTA-MOTOS et al., 2017).

With the reduction in cell turgor there is a decrease in the growth rate of the plants. This trend can be attributed to the fact that the plant, to achieve ionic and osmotic homeostasis, spends an amount of energy to accumulate sugars, organic acids and ions in the vacuole, which could be used for growth (SANTOS et al., 2012).
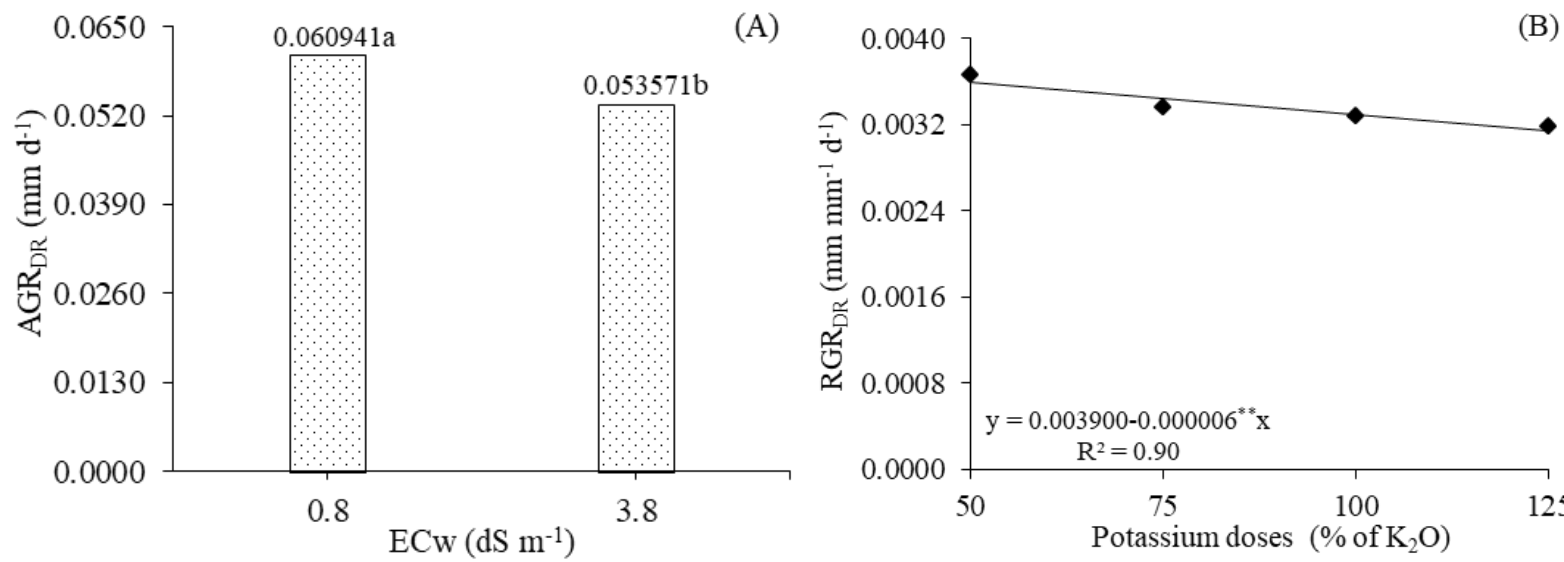

Figure 1. Absolute growth rate in stem diameter of rootstock - $A_{G R} R_{D R}(A)$ of West Indian cherry cv. BRS 366-Jaburu plants irrigated with saline waters - ECW (A) and relative growth rate in stem diameter of rootstock - $\mathrm{RGR}_{\mathrm{DR}}(\mathrm{B})$ as a function of potassium doses (B), in the period from 100 to 465 days after transplanting. Means followed by different letters indicate difference between treatments by Tukey test, $\mathrm{p}<0.05$. 
The relative growth rate is an index which reflects the efficiency of use of the reserves, since it represents the capacity of the plant to produce new material, as a function of the already existing material (BEZERRA et al., 2016). It can be observed that the $\mathrm{K}$ doses caused linear reduction in the $\mathrm{RGR}_{\mathrm{DR}}$ and, according to the regression equation (Figure 1B), it decreased by $3.84 \%$ for every $25 \%$ increase in $\mathrm{K}_{2} \mathrm{O}$ doses. The highest dose of $\mathrm{K}_{2} \mathrm{O}$ $(125 \%)$ led to a reduction in $\mathrm{RGR}_{\mathrm{DR}}$ of $0.0040 \mathrm{~mm}$ $\mathrm{mm} \mathrm{d}^{-1}$ in comparison to plants cultivated with $50 \%$ of the recommendation of Musser (1995). Reduction in $\mathrm{RGR}_{\mathrm{DR}}$ due to $\mathrm{K}_{2} \mathrm{O}$ doses may be related to the competitive absorption relative to the total sum of cations inside the plant, because high $\mathrm{K}$ concentration in soil solution may induce deficiencies of calcium and magnesium, reducing the growth of the entire plant (CRUZ et al., 2018). Andriolo et al. (2010), evaluating the effects of K doses supplied by fertigation on strawberry growth and production, concluded that the increase of $\mathrm{K}$ concentration in the nutrient solution reduced growth, production and organoleptic quality of strawberry fruits.

Regarding the absolute growth rate in diameter of the rootstock of West Indian cherry cv. BRS 366-Jaburu, the means comparison test (Figure 2A) showed that plants irrigated with water of electrical conductivity of $0.8 \mathrm{dS} \mathrm{m}^{-1}$ were significantly different from those subjected to $\mathrm{ECW}$ of $3.8 \mathrm{dS} \mathrm{m}^{-1}$. In general, the deleterious effect of salt stress (Figure 2A) was more intense on plants under $\mathrm{ECw}$ of $3.8 \mathrm{dS} \mathrm{m}^{-1}$, whose reduction in $\mathrm{AGR}_{\mathrm{DS}}$ was $0.00841 \mathrm{~mm} \mathrm{~d}^{-1}$, compared to those subjected to the lowest level of water salinity $\left(0.8 \mathrm{dS} \mathrm{m} \mathrm{m}^{-1}\right)$. As observed for $\mathrm{AGR}_{\mathrm{DR}}$ (Figure $1 \mathrm{~A}$ ), the reduction in $A_{G R}$ may result from the alterations which occur in the osmotic potential of the soil solution, due to the increment in salinity levels, which causes difficulty in the absorption of water and nutrients by plants, inducing stomatal closure for increasing the resistance to $\mathrm{CO}_{2}$ diffusion, leading to decrease in $\mathrm{CO}_{2}$ assimilation rate. In addition, it may lead to accumulation of solutes and antioxidants, which results in reduction of growth (FREIRE et al., 2014).

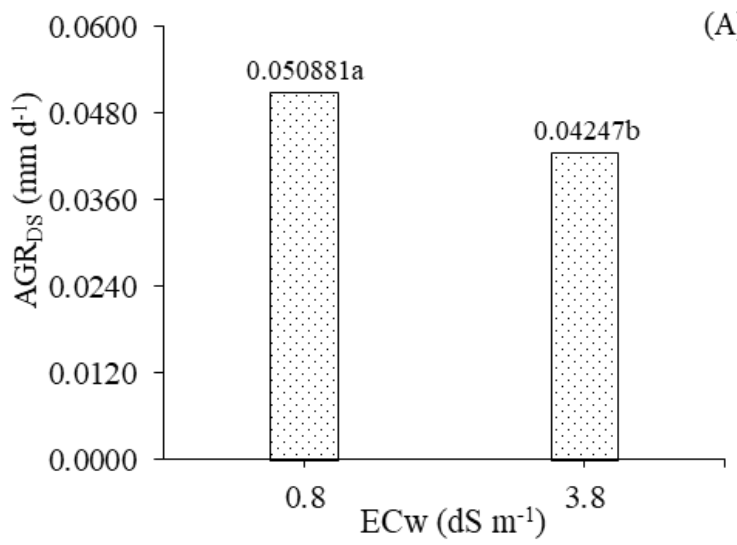

(A)

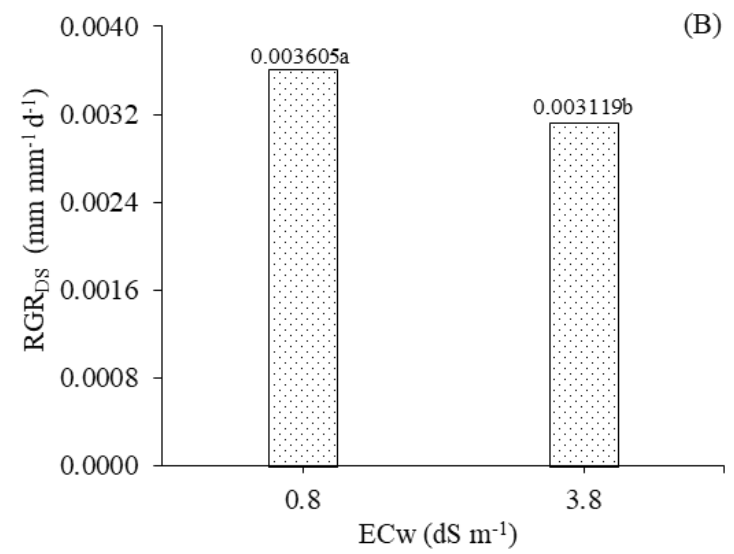

Figure 2. Absolute growth rate - $\mathrm{AGR}_{\mathrm{DS}}(\mathrm{A})$ and relative growth rate $-\mathrm{RGR}_{\mathrm{DS}}(\mathrm{B})$ in stem diameter of the scion of West Indian cherry cv. BRS 366-Jaburu plants irrigated with saline waters - ECw, in the period from 100 to 465 days after transplanting. Means followed by different letters indicate difference between treatments by Tukey test, $\mathrm{p}<0.05$.

The relative growth rate in diameter of scion of West Indian cherry plants was significantly influenced by irrigation with saline water and, according to the means comparison test (Figure 2B), the $\mathrm{RGR}_{\mathrm{DS}}$ of plants irrigated with $\mathrm{ECw}$ of $3.8 \mathrm{dS} \mathrm{m}^{-1}$ was statistically lower than that of plants growth under the lowest level of water salinity $(0.8$ $\mathrm{dS} \mathrm{m}{ }^{-1}$ ), i.e., imposition of water stress through the use of saline waters leads to inhibition of growth in West Indian cherry plants. Comparatively, the $\mathrm{RGR}_{\mathrm{DS}}$ of plants irrigated with ECw of $3.8 \mathrm{dS} \mathrm{m}^{-1}$ was reduced by $0.000486 \mathrm{~mm} \mathrm{~d}^{-1}$ compared to those under the lowest ECW level $\left(0.8 \mathrm{dS} \mathrm{m}^{-1}\right)$. Thus, the data obtained for $\mathrm{AGR}_{\mathrm{DR}}, \mathrm{AGR}_{\mathrm{DS}}$ and $\mathrm{RGR}_{\mathrm{DS}}$ demonstrate that West Indian cherry growth is negatively affected by the increase in irrigation water salinity, a fact previously elucidated by Bezerra et al. (2018) and Freire et al. (2014) in guava and yellow passion fruit crops, respectively. Corroborating the results obtained in the present study, Mesquita et al. (2012) evaluated the effects of saline water irrigation on the absolute and relative growth rates of yellow passion fruit seedlings in soil with bovine biofertilizer and also found that the increase in water salinity caused reduction in the absolute and relative growth rates in stem diameter.

According to the summary of analysis of variance for post-harvest fruit quality (Table 2), the interaction between factors (SL $x \quad K D)$ was significant for FPD, $\mathrm{pH}$, ANT and SS. Irrigation water salinity had significant effect on equatorial and polar diameters, hydrogen potential and contents of anthocyanins and soluble solids of the fruits. The $\mathrm{K}$ doses significantly influenced polar diameter and the contents of anthocyanins and soluble solids. 
Table 2. Summary of analysis of variance for equatorial diameter (FED), polar diameter (FPD), hydrogen potential (pH), anthocyanins (ANT), soluble solids (SS) of fruits of West Indian cherry cv. BRS 366-Jaburu under saline water irrigation and fertilization with potassium doses.

\begin{tabular}{lcccccc}
\hline \multirow{2}{*}{ Source of variation } & \multirow{2}{*}{ DF } & \multicolumn{5}{c}{ Mean squares } \\
\cline { 3 - 7 } & & FED & FPD & $\mathrm{pH}$ & ANT & SS \\
\hline Saline levels (SL) & 1 & $28.12^{*}$ & $69.08^{* *}$ & $0.70^{*}$ & $0.73^{* *}$ & $16.83^{* *}$ \\
K dose (KD) & 3 & $1.41^{\text {ns }}$ & $9.15^{*}$ & $0.22^{\text {ns }}$ & $0.06^{*}$ & $1.91^{* *}$ \\
Linear regression & 1 & $3.05^{\text {ns }}$ & $26.22^{* *}$ & $0.62^{*}$ & $0.02^{\text {ns }}$ & $4.21^{* *}$ \\
Quadratic regression & 1 & $0.02^{\text {ns }}$ & $0.82^{\text {ns }}$ & $0.04^{\text {ns }}$ & $0.17^{*}$ & $0.003^{\text {ns }}$ \\
Interaction (SL x KD) & 3 & $0.35^{\text {ns }}$ & $5.14^{*}$ & $0.26^{*}$ & $0.12^{*}$ & $0.61^{* *}$ \\
Blocks & 2 & $0.93^{\text {ns }}$ & $0.05^{\text {ns }}$ & $0.05^{\text {ns }}$ & $0.02^{\text {ns }}$ & $0.003^{\text {ns }}$ \\
Residue & 14 & 2.06 & 1.06 & 0.04 & 0.02 & 0.003 \\
\hline CV (\%) & & 7.88 & 4.57 & 5.76 & 40.53 & 0.75 \\
\hline
\end{tabular}

ns, $*, * *$ Respectively, not significant, significant at $\mathrm{p}<0.05$ and $\mathrm{p}<0.01$.

As observed for growth variables, saline water irrigation also negatively influenced the size of West Indian cherry fruits, evidenced in the present study by the equatorial diameter. Based on the means comparison test (Figure 3A), plants under $\mathrm{ECw}$ of $3.8 \mathrm{dS} \mathrm{m}^{-1}$ differed statistically from those subjected to salinity of $0.8 \mathrm{dS} \mathrm{m}^{-1}$. In the comparison between plants subjected to $\mathrm{ECw}$ of $3.8 \mathrm{dS} \mathrm{m}^{-1}$ and those under the lower level of water salinity $\left(0.8 \mathrm{dS} \mathrm{m}^{-1}\right)$, there was a reduction of $2.17 \mathrm{~mm}$ in FED. Reduction in the size of West Indian cherry fruits, observed in the present study through the equatorial diameter, may result from the alterations which occurred in the growth of the plants, due to the interference of the salts in their nutrition. In addition, as soil salinity increases, water availability to the crop decreases because the plant begins to require more energy to absorb water from the soil, reducing its growth and consequently resulting in the formation of smaller fruits (NOBRE et al., 2013).
The interaction between water salinity levels and $\mathrm{K}$ doses significantly interfered with the polar diameter of West Indian cherry fruits and, based on the regression analysis (Figure 3B), the data of plants irrigated with ECw of $0.8 \mathrm{dS} \mathrm{m}^{-1}$ were described by a linear decreasing model. It can be noted that, when irrigation was conducted using water with the lowest level of salinity $\left.(\mathrm{ECW}=0.8 \mathrm{dS} \mathrm{m})^{-1}\right)$, the highest value of FPD $(27.92 \mathrm{~mm})$ occurred when plants were fertilized with $50 \%$ of $\mathrm{K}_{2} \mathrm{O}$, with reduction of $6.73 \%$ for every $25 \%$ increase in $\mathrm{K}_{2} \mathrm{O}$ dose, reaching minimum value of $21.40 \mathrm{~mm}$ in those subjected to the highest dose of $\mathrm{K}_{2} \mathrm{O}(125 \%)$. According to the regression analysis (Figure 3B), the FPD data of plants cultivated using water with the highest level of salinity $\left(3.8 \mathrm{dS} \mathrm{m}^{-1}\right)$ were described by a quadratic model, and the highest value $(21.93 \mathrm{~mm})$ was obtained at the estimated dose of $87 \%$ of $\mathrm{K}_{2} \mathrm{O}$. On the other hand, West Indian cherry plants under fertilization with $125 \%$ of $\mathrm{K}_{2} \mathrm{O}$ produced fruits with lower polar diameter $(17.54 \mathrm{~mm})$.
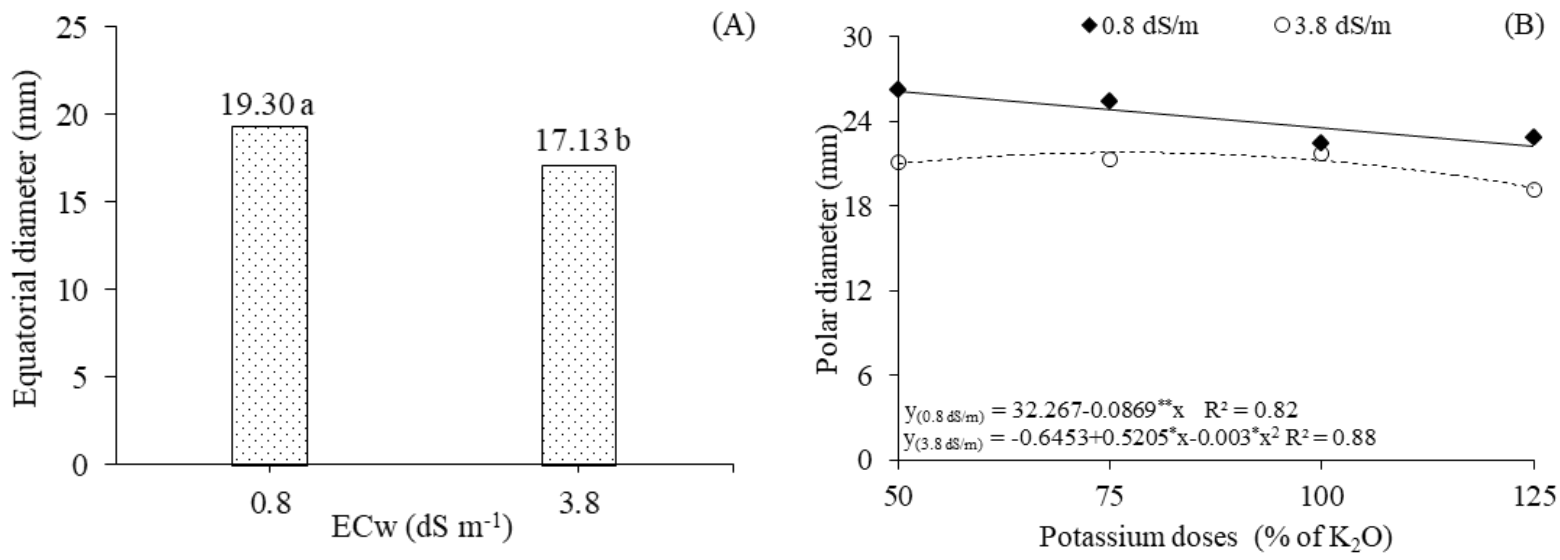

Figure 3. Equatorial diameter (A) of fruits of West Indian cherry under irrigation with saline water - ECw and polar diameter (B) of fruits of West Indian cherry cv. BRS 366-Jaburu, as a function of the interaction between ECw levels and potassium doses. Means followed by different letters indicate difference between treatments by Tukey test, $\mathrm{p}<0.05$. 
Reduction in the size of West Indian cherry fruits may be related to the source of $\mathrm{K}$ used, because the supply of potassium chloride, a fertilizer with high salt index, may result in intensification of the osmotic stress (PRAZERES et al., 2015), inhibiting the absorption of water and nutrients by plants. In addition, high doses of $\mathrm{K}$ in the soil solution can cause competition with the cations calcium and magnesium for the same absorption site on the roots, resulting in antagonism between them, because the imbalance of concentration causes reciprocal alterations in terms of availability, absorption and translocation in the plant (PINHEIRO et al., 2011). This situation may cause nutritional deficiencies and consequently result in the formation of fruits with lower diameter. A situation similar to that observed in the present study was also verified by Bonifácio et al. (2018) when evaluating the effects of different salinities of irrigation water $(\mathrm{ECW}$ $=0.3 ; 1.1 ; 1.9 ; 2.7$ and $3.5 \mathrm{dS} \mathrm{m}^{-1}$ ) on the growth of guava rootstocks cv. Paluma fertilized with increasing doses of potassium $(70,100,130$ and $160 \% \mathrm{~K}_{2} \mathrm{O}$ of recommendation). According to these authors, the increase in the $\mathrm{K}_{2} \mathrm{O}$ dose does not always result in beneficial effects for the plants, and the salinity from the fertilizer, caused by high concentrations of $\mathrm{K}_{2} \mathrm{O}$ applied, may even be more harmful than that caused by high concentrations of salts like sodium and chloride.

The levels of irrigation water salinity, when analyzed in interaction with $\mathrm{K}$ doses, also caused significant difference in the hydrogen potential of West Indian cherry pulp (Table 2). According to the regression equations (Figure 4A), plants irrigated with $\mathrm{ECW}$ of $0.8 \mathrm{dS} \mathrm{m}^{-1}$ showed the highest value of $\mathrm{pH}(3.20)$ when fertilized with the estimated dose of $84 \%$ of $\mathrm{K}_{2} \mathrm{O}$. From this level on, pulp $\mathrm{pH}$ increased sharply as $\mathrm{K}_{2} \mathrm{O}$ doses in high salinity water, and a maximum estimated value of 4.31 was obtained in plants under $125 \%$ of the recommendation of $\mathrm{K}_{2} \mathrm{O}$. This is a response of extreme importance because the increase in $\mathrm{pH}$ reduces the acidic character of the pulp of West Indian cherry fruits. This fact may be related to the accumulation of sugars inside the fruits (GURGEL et al., 2010). Furthermore, due to the consumption of organic acids during fruit ripening because of the respiratory activity of the cells, there may be an increment in the values of pulp $\mathrm{pH}$ (SILVA et al., 2005). Dias et al. (2011), analyzing the chemical quality of the pulp of yellow passion fruits, as a function of irrigation with saline water (ECw varying from 0.5 to $4.5 \mathrm{dS} \mathrm{m}^{-1}$ ) in an open field orchard, observed that there was no significant alteration in the $\mathrm{pH}$ of the pulp of passion fruits.
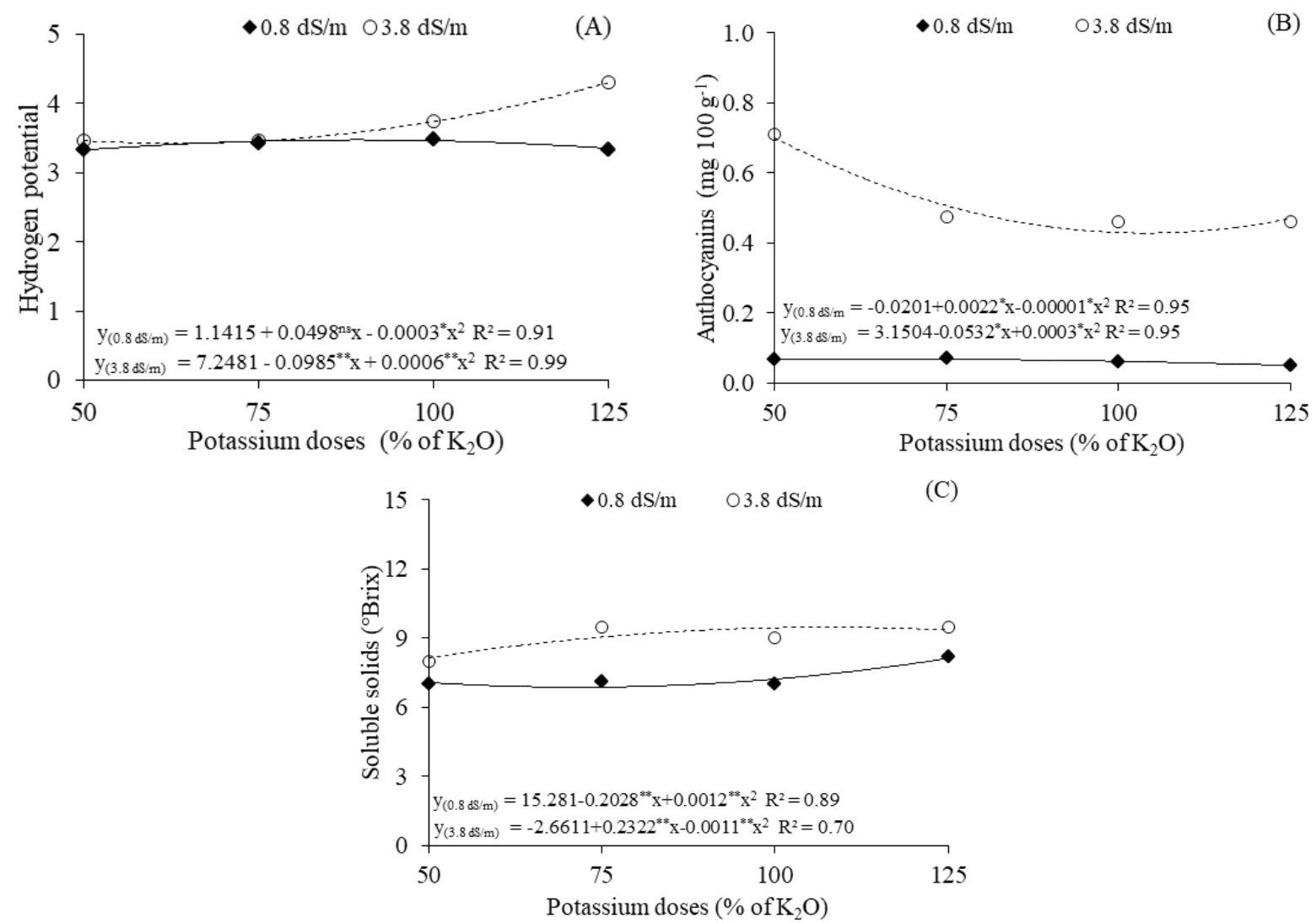

Figure 4. Hydrogen potential (A), anthocyanins (B) and soluble solids (C) in the pulp of West Indian cherry cv. BRS 366 -Jaburu, as a function of the interaction between water salinity levels - $\mathrm{ECw}$ and potassium doses. 
Anthocyanin contents in West Indian cherry fruits were significantly altered by the interaction between factors (SL $x \mathrm{KD}$ ). According to the regression equations (Figure 4B), it can be observed that the data were described by a quadratic model. At the lowest level of salinity $\left(0.8 \mathrm{dS} \mathrm{m}^{-1}\right)$, the highest ANT content $\left(0.099 \mathrm{mg} 100 \mathrm{~g}^{-1}\right)$ in West Indian cherry fruits was obtained when plants were grown under the estimated dose of $116 \%$ of $\mathrm{K}_{2} \mathrm{O}$. For plants cultivated with $\mathrm{ECw}$ of $0.8 \mathrm{dS} \mathrm{m} \mathrm{m}^{-1}$, ANT contents increased by $0.034 \mathrm{mg} 100 \mathrm{~g}^{-1}$ between the lowest and highest doses of $\mathrm{K}$. On the other hand, when plants were subjected to irrigation using water with the highest level of salinity $\left(3.8 \mathrm{dS} \mathrm{m}^{-1}\right)$, the highest estimated value for ANT $\left(0.794 \mathrm{mg} 100 \mathrm{~g}^{-1}\right)$ occurred at the dose of $50 \%$ of the recommendation of $\mathrm{K}_{2} \mathrm{O}$. From the data obtained under ECw of 0.8 and $3.8 \mathrm{dS}$ $\mathrm{m}^{-1}$, it can be observed that the highest synthesis of anthocyanin occurred in plants subjected to water salinity of $3.8 \mathrm{dS} \mathrm{m} \mathrm{m}^{-1}$. This fact is extremely important because anthocyanins can act as nonenzymatic antioxidants, since their flavylium cation oxidized by $\mathrm{O}_{2}^{-}$provides oxidative protection in cell membranes and organelles (AMARANTE et al., 2007).

The content of soluble solids in West Indian cherry pulp was influenced by the interaction between water salinity levels and $\mathrm{K}$ doses. According to the regression equations (Figure 4C), the data of SS were best described by a quadratic model. Based on the regression equation (Figure 4C), plants irrigated with ECw of $0.8 \mathrm{dS} \mathrm{m}^{-1}$ showed increase in the contents of soluble solids in the pulp as the $\mathrm{K}_{2} \mathrm{O}$ doses increased, and the maximum value of $8.68{ }^{\circ}$ Brix was obtained in plants under $125 \%$ of the recommendation of $\mathrm{K}_{2} \mathrm{O}$. Plants under irrigation with $\mathrm{ECw}$ of $3.8 \mathrm{dS} \mathrm{m}^{-1}$ reached maximum $\mathrm{SS}$ value $\left(9.17^{\circ} \mathrm{Brix}\right)$ at $\mathrm{K}_{2} \mathrm{O}$ dose of $115 \%$. In a joint analysis of the data of plants subjected to ECw levels of 0.8 and $3.8 \mathrm{dS} \mathrm{m}^{-1}$, it is possible to observe that those grown at the highest level of salinity reached higher SS content. The values found for SS (Figure 4C) are within the range recommended for the cv. BRS 366Jaburu, 9.33 ${ }^{\circ}$ Brix, according to Embrapa (2012). Thus, the increase in the content of soluble solids probably occurred due to the osmotic adjustment by the plant, in an attempt to reach equilibrium with the osmotic potential of the soil solution (FERREIRA NETO et al., 2002). Differently from the data obtained in the present study, Dias et al. (2011) evaluated the effects of irrigation water salinity (from 0.5 to $4.5 \mathrm{dS} \mathrm{m}^{-1}$ ) on the chemical quality of yellow passion fruits and observed that the contents of soluble solids decreased with increasing $\mathrm{ECW}$.

\section{CONCLUSIONS}

The interaction between salt levels and potassium doses is significant for the hydrogen potential and contents of soluble solids and anthocyanins in fruits of West Indian cherry, cv. BRS 366-Jaburu, with the highest values obtained in plants fertilized with 125,125 and $50 \%$ of the $\mathrm{K}_{2} \mathrm{O}$ recommendation and under water salinity of 3.8, 3.8 and $0.8 \mathrm{dS} \mathrm{m}^{-1}$, respectively.

Irrigation water salinity of $3.8 \mathrm{dS} \mathrm{m}^{-1}$ inhibits the absolute and relative growth in diameter of rootstock and scion of West Indian cherry, from 100 to 465 days after transplanting.

Potassium doses did not attenuate the deleterious effects of salt stress on the relative growth in rootstock diameter and polar diameter of West Indian cherry fruits.

The contents of soluble solids in the pulp of West Indian cherry fruits increases with the doses of $\mathrm{K}_{2} \mathrm{O}$.

\section{ACKNOWLEDGMENTS}

To the National Program of Post-Doctorate (PNPD/CAPES/UFCG), for granting the scholarship to the first author and to the National Institute of Science and Technology in Salinity - INCTSal, for funding the project.

\section{REFERENCES}

ACOSTA-MOTOS, J. R., et al. Plant responses to salt stress: adaptive mechanisms. Agronomy, 18: 138, 2017.

ALVARENGA, C. F. S. et al. Morfofisiologia de aceroleira irrigada com águas salinas sob combinações de doses de nitrogênio e potássio. Revista de Ciências Agrárias, 42: 194-205, 2019.

AMARANTE, L. et al. Teores de clorofilas em soja associada simbioticamente com diferentes estirpes de Bradyrhizobium sob alagamento. Revista Brasileira de Biociências, 5: 906-908, 2007.

ANDRIOLO, J. L. et al. Doses de potássio e cálcio no crescimento da planta, na produção e na qualidade de frutas do morangueiro em cultivo sem solo. Ciência Rural, 40: 267-272, 2010.

ASSOCIATION OF OFFICIAL ANALYTICAL CHEMISTS - AOAC. Official methods of analysis of the Association of Official Analytical Chemists, (method 942.15 A). Arlington: A. O. A. C, 1995. chapter $37.10 \mathrm{p}$.

BENINCASA, M. M. P. Análise de crescimento de plantas: noções básicas. 2. ed. Jaboticabal, SP: FUNEP, 2003. 41 p. 
BEZERRA, I. L. et al. Morphophysiology of guava under saline water irrigation and nitrogen fertilization. Revista Brasileira de Engenharia Agrícola e Ambiental, 22: 32-37, 2018.

BEZERRA, J. D., et al. Crescimento de dois genótipos de maracujazeiro-amarelo sob condições de salinidade. Revista Ceres, 63: 502-508, 2016.

BONIFÁCIO, B. F. et al. Efeitos da adubação potássica e irrigação com águas salinas no crescimento de porta-enxerto de goiabeira. Revista de Ciências Agrárias, 41: 971-980, 2018.

BRASIL - Ministério da Saúde. Agencia Nacional de Vigilância Sanitária. Métodos físico-químicos para análise de alimentos/Ministério da Saúde, Agência Nacional de Vigilância Sanitária. Brasília: Ministério da Saúde, 2005. 1020 p.

CAVICHIOLI, J. C. et al. Reação de aceroleira (Malpighia emarginata DC.) à Meloidogyne enterolobii. Revista Brasileira de Fruticultura, 36: 156-160, 2014.

COSTA, M. E. et al. Estratégias de irrigação com água salina na mamoneira. Revista Ciência Agronômica, 44: 34-43, 2013.

CRUZ, J. L. et al. Salinity reduces nutrients absorption and efficiency of their utilization in cassava plants. Ciência Rural, 48: e20180351, 2018.

DEMBITSKY, V. et al. The multiple nutrition properties of some exotic fruits: biological activity and active metabolites. Food Research International, 44: 1671-1701, 2011.

DIAS, T. J. et al. Qualidade química de frutos do maracujazeiro-amarelo em solo com biofertilizante irrigado com águas salinas. Revista Brasileira de Engenharia Agrícola e Ambiental, 15: 229-236, 2011.

EMPRESA BRASILEIRA DE PESQUISA AGROPECUÁRIA -EMBRAPA. Cultivar Acerola BRS 366-Jaburu. 1 ed. Fortaleza, CE: Embrapa Agroindústria Tropical, 2012. $2 \mathrm{p}$

FERREIRA, D. F. SISVAR: a computer statistical analysis system. Ciência e Agrotecnologia, 35: 1039-1042, 2011.

FERREIRA NETO, M. et al. Qualidade do fruto verde de coqueiro em função da irrigação com água salina. Revista Brasileira de Engenharia Agrícola e Ambiental, 6: 69-75, 2002.

FREIRE, J. L. et al. Rendimento quântico e trocas gasosas em maracujazeiro amarelo sob salinidade hídrica, biofertilização e cobertura morta. Revista Ciência Agronômica, 45: 82-91, 2014.

GOMES, M. A. C. et al. Salinity effects on photosynthetic pigments, proline, biomass and nitric oxide in Salvinia auriculata Aubl. Acta Limnologica Brasiliensia, 29: 1-13, 2017.

GURGEL, M. T., et al. Qualidade pós-colheita de variedades de melões produzidos sob estresse salino e doses de potássio. Revista Brasileira de Ciências Agrárias, 5: 398-405, 2010.

MATIAS, J. R. et al. Hydropriming as inducer of salinity tolerance in sunflower seeds. Revista Brasileira de Engenharia Agrícola e Ambiental, 22: 255-260, 2018.

MEDEIROS, J. F., et al. Crescimento e acúmulo de $\mathrm{N}, \mathrm{P}$ e $\mathrm{K}$ pelo meloeiro irrigado com água salina. Horticultura Brasileira, 26: 452-457, 2008.

MELO, A. S., et al. Chlorophyll and macronutrients content in leaf tissue of Musa sp 'Prata-Anã' under fertigation. African Journal of Agricultural Research, 9: 1714-1720, 2014.

MESQUITA, F., et al. Crescimento absoluto e relativo de mudas de maracujazeiro sob biofertilizante e águas salinas. Revista de Ciências Agrárias, 35: 222-239, 2012.

MURRAY, J. R.; HACKETT, W. P. Difydroflavonol reductase activity in relation to differential anthocyanin accumulation in juvenile and mature phase Hedera helix L. Plant Physiology, 97: 343351,1991 .

MUSSER, R. S. Tratos culturais na cultura da acerola. In: SÃO JOSÉ, A. R.; ALVES, R. E. (Eds.). Acerola no Brasil: Produção e mercado. Vitória da Conquista, BA: UESB, 1995. cap. 3, p. 47-52.

NOBRE, R. G. et al. Emergência, crescimento e produção da mamoneira sob estresse salino e adubação nitrogenada. Revista Ciência Agronômica, 44: 76-85, 2013.

PINHEIRO, J. B. et al. Severidade da ferrugem da soja em função do suprimento de potássio e cálcio em solução nutritiva. Revista Ceres, 58: 43-50, 2011.

PRAZERES, S. et al. Crescimento e trocas gasosas de plantas de feijão-caupi sob irrigação salina e doses de potássio. Revista Agro@mbiente On-line, 9: 111-118, 2015.

RICHARDS, L. A. Diagnosis and improvement of saline and alkali soils. Washington: U.S, 
Department of Agriculture, 1954. 160 p.

SANTOS, D. B. et al. Produção e parâmetros fisiológicos do amendoim em função do estresse salino. Idesia, 30: 69-74, 2012.

SILVA, A. A. R. et al. Potassium fertilization in the cultivation of colored cotton irrigated with saline water. Revista Brasileira de Engenharia Agrícola e Ambiental, 21: 628-633, 2017.

SILVA, E. N. et al. Salt stress induced damages on the photosynthesis of physic nut young plants. Scientia Agrícola, 68: 62-68, 2011.

SILVA, J. L. et al. Uso de águas salinas como alternativa na irrigação e produção de forragem no semiárido nordestino. Revista Brasileira de Engenharia Agrícola e Ambiental, 18: 66-72, 2014.

SILVA, T. V. et al. Influência dos estádios de maturação na qualidade do suco do maracujáamarelo. Revista Brasileira de Fruticultura, 27: 472-475, 2005.

TEIXEIRA, P. C. et al. Manual de métodos de análise de solo. 3. ed. Brasília, DF: Embrapa, 2017. $573 \mathrm{p}$. 